\title{
The Women's Reservation Bill Of India; A Step Towards Equality Or An Empty Promise
}

\author{
Sejpal SWAPNEEL \\ Gujarat National Law University \\ swapneel42@gmail.com
}

Makale Başvuru Tarihi / Received: 16.11.2021

Makale Kabul Tarihi / Accepted: 23.12.2021

Makale Türü / Article Type: Araştırma Makalesi
Keywords:
Women
Empowerment,
Reservation,
Constitution,
Human Rights,
Elections

\section{ABSTRACT}

Women consist of nearly half of the population of the country, yet their representation in the higher legislative bodies like the State Assemblies and Houses of Parliament remains abysmal. This leads to their concerns being sidelined. Thus, it is important that they are given due representation in these bodies, by reservation, if necessary, to ensure that they are also equally heard. The Women's Reservation bill is a progressive attempt to remedy this situation. However, it has been in a state of inertia since the last two decades due to the unwillingness of certain political parties to agree to it. With the change in the times, it is imperative to bring men and women on an equal footing and hence, this paper attempts to critically analyze the bill and its implementation.. 
“Women are one half of the world, but... it remains a man's world. The laws are man's laws, the government a man's government, the country a man's country. This man's world must become a man's and a woman's world. Why are we afraid? It is the next step forward in the path to sunrise, and the sun is rising over a new heaven and a new earth (Singhvi, 1997)."

\section{INTRODUCTION TO THE HISTORICAL CONDITIONS OF WOMEN}

Women, a group that has always accounted for nearly half of the population since the dawn of civilization, yet continues to be one of the most deprived groups amongst the world. A group, which holds the ability to further mankind but is called the weaker sex. A group which on one hand has always stood by, supported and furthered the cause of their male counterparts but on the other hand has been deprived of the most basic necessities of life. Globally, women account for nearly two thirds of the world's poor and illiterate. There has been a systematic denial of access to social, economic, legal, medical and educational resources to women, leaving them extremely vulnerable and dependent on their male counterparts. (UN Women)

In India, women have been historically in a position that has been less advantageous than that enjoyed by men. India has been for long a country whose culture prioritizes its sons over daughters. A rigid patriarchal setup meant that in families, it was the male members and the sons who were considered to be the important members of the household while the role of the women was reduced to that of child bearers, cooks and servants. Their identity was defined by their relation to the males of the house. This concept of women having an identity attached to the male members was so pronounced that when a woman's husband died, it was the custom to burn her alive on the pyre with him, whether she wanted to do it or not. This was called 'Sati'. Although the Britishers had outlawed Sati in the mid-19th Century itself, Sati was been practised widely as late as the early 1950s, almost a hundred years after it had been outlawed.

\subsection{Early Attempts Of The Women's Rights Movement Of India}

Even though Indian women have been encumbered by these problems since centuries, it was only in the early 20th Century that women began to take action to demand equal political rights by forming formalized organizations. The first such attempt was made in 1917 when prominent member of the Congress Party, Sarojini Naidu led a delegation of women from all over the country to the then Secretary of State and Viceroy of India demanding that the Britishers accord a status of equal citizens to them in the self-governing territory of India in the British Empire (Forbes, 1996). It was this event that caused the awakening in the women of India and served as the spark that lit the fire of the movement of demanding equal rights.

This however, was not immune from scepticism from all quarters of the male dominated society. British critics of the Indian way of life lamented that it was the urban and elite class of women that were usurping the rights that the rural and backward women were in dire need of. Even Mahatma Gandhi, who was himself a champion of women's rights, did not support this movement because he felt that it would divide the nation and would hamper the movement for independence (Forbes, 1996).

Indian women campaigning for their rights were faced with another dilemma when Indian men who encouraged female education and the formation of structural organizations for women did not relish hearing women speak about the evils of patriarchy. Women found themselves in a very difficult position due to the varying oppositionsif they spoke bluntly about the sufferings of Indian women, they were labelled disloyal to their culture; if they remained silent, they were essentially feeding into the stereotypes of being timid, ignorant, and subordinate (Forbes, 1996).

Despite all the odds stacked against them, these women managed to secure suffrage rights not just for themselves, but for all the women in the country. By 1930, all the provinces of British India had granted voting rights to women and allowed them to become members of the governing bodies in limited numbers. This was a small step but a step in the right direction nonetheless. It was this movement that helped convince the members of the Constituent Assembly of a free and independent India that women ought to be considered as equal citizens if the country was to walk on the path of progress.

Right from the time the drafting of the Constitution of India was put into motion; certain rights for women were envisaged and entered into the chapter III containing the fundamental rights portion of the supreme document of the nation along with those guaranteed to the backward and oppressed classes. These rights not just guaranteed equality between both the sexes in the society but also empowered the state to actively make laws favouring women (Articles 15 and 16 of the Constitution). This was done because the members of the Constituent Assembly 
were aware of the historical injustices that had been done to women. These rights were meant to ensure that women actually enjoyed equal rights as their male counterparts and were equal citizens in the nation. These rights would provide women with additional benefits to bring them on par with the societal standards. It was as if the state was deliberately engaging in discrimination in favour of women to bring about equality in the society.

\subsection{Post-Independence Period And Women's Rights}

Since independence, successive governments of the country tried to implement the aforementioned concept of active legislation favouring women in order to compensate for the centuries of grave injustices that had befallen upon the nation's women. Many laws were enacted in an attempt to eradicate the social evils towards women. Some prominent examples of these are the Immoral Traffic (Prevention) Act, 1956, The Dowry Prohibition Act, 1961 (Amended in 1986), The Indecent Representation of Women (Prohibition) Act, 1986, The Commission of Sati (Prevention) Act, 1987, Protection of Women from Domestic Violence Act, 2005 and The Sexual Harassment of Women at Workplace (PREVENTION, PROHIBITION and REDRESSAL) Act, 2013. Also important is the movement for equal pay for equal work under the aegis of the Articles 39(d) and 41 of the Directive Principles of State Policy (DPSP) of the Constitution of India (National Commission for Women).

Despite all these laws for protecting and empowering women, the on-ground situation saw no visible improvement. The most prominent example of this vast disconnect between the legislation and its implementation was visible in the dowry cases. Dowry is defined as the property and gifts given to a daughter by her parents at the time of marriage-traditionally known as stridhan. It is intended to provide material security to a woman who is otherwise denied equal property rights under the law. Dowry in its more contemporary meaning refers to a more recent practice of extraction of property from the wife and her parents by her husband and in-laws (Kapur and Cossman, 1996)

Despite having a law since 1961, dowry harassments and dowry killings reached all-time highs in the 1970s and the early 1980s (Ray, 1999). It was only after the amendment criminalizing asking for dowry or harassing the woman for dowry was passed, the menace reduced. Nevertheless, dowry harassment and dowry deaths prevail in many parts of the country even today.

The watershed moment in the empowerment was the liberalization of the Indian Economy in the early 1990s. It was during this time that an entire generation of women, who had freshly completed schooling, was entering the colleges of the country. With the tide of liberalization came the wave of ideals and cultural influences of the western countries. Additionally, this was also the period when the need for local level bodies was felt and thus came into existence the panchayats and the municipal bodies vide the 73rd and the 74th Constitutional Amendments respectively. It was the empowered status of the newly educated women and the opportunity of setting up an entirely new system of representation that enabled the government to introduce a provision for reserving one-third of the total seats for women. This decision by the government was surely a step closer to female empowerment and participation in decision making at the local level. By compulsorily reserving one-third of seats for female candidates, the state made them effective stakeholders in the decision making and implementing process. This step fostered an environment of inclusiveness and equal participation of all in the democratic process of self-governance.

\section{HISTORY OF THE WOMEN'S RESERVATION BILL}

Looking at the success of the model of reservation in the local bodies, the Women's Reservation Bill was introduced on 12th September 1996 in the Lok Sabha. In order to achieve consensus amongst the members, the bill was then kept inactive for nearly two years. When it was reintroduced, there was stiff opposition from the male members of the parliament stating that such a bill was ludicrous and that its passing would endanger the fabric of Indian society and its values. According to them, the rightful place of women was at home taking care of family and children (National Public Radio, 1998). Owing to this opposition, the bill had to be shelved once again.

The bill was then tabled for the third time before the house. Despite pledges of support by the then Prime Minister Atal Bihari Vajpayee and the main opposition party, the Indian National Congress, the bill could not pass due to the stern opposition of Lalu Prasad Yadav of the Rashtriya Janta Dal and Mulayam Singh Yadav of the Samajwadi Party (Handoo, 1998). Although successive governments kept the bill alive by listing it on the legislative agenda, it took almost ten years for it to be presented for debate, this time not even before the Lok Sabha but before the Rajya Sabha. The Rajya Sabha took up the bill and sent it to a Joint Parliamentary Committee headed by MP Geeta Mukherjee to critically examine the provisions of the bill, compare it with the earlier bills and present suggestion before the house. The bill was finally passed in 2010 amid much ruckus and physical altercations 
between the government and the opposition benches as the the Constitution (One Hundred and Eighth Amendment) Bill, 2008 with the following broad set of objectives-

1. Reservation of one-third of all seats in the Lok Sabha and state legislative assemblies.

2. The allocation of these prescribed seats will be done by an authority prescribed by the parliament.

3. From within the seats reserved for women, one-third will be reserved for Scheduled Castes and Scheduled Tribes.

4. Reserved seats will be allotted by rotation to different constituencies in the Lok Sabha or the assemblies of the state/union territory.

5. This 33 percent reservation will cease to exist after fifteen years of the commencement of the law (Virk, 2018).

This bill was then introduced in the Lok Sabha as an item on the legislative agenda but was never actually brought up for debate. Successive governments have followed the suit and have retained the bill on the legislative agenda but have never actually brought it up for debate in the house. In the words of CPI (M) MP Brinda Karat "The Bill was adopted by the Rajya Sabha in 2010. The distance between the Rajya Sabha and the Lok Sabha is just a five minute walk. But the Bill has not moved for several years." (Chatterjee, 2017)

\section{REASONS FOR SUPPORT AND OPPOSITION TO THE BILL}

Proponents for the reservation base their arguments on the principles of justice, equity, good conscience, morality and ethics. Concepts of redistribution, representation, integration, mobilization, stimulation, fairness, and development are at the heart of the movement. These parties realize that reservation is not the end of the struggle for truly equal status for women in society but believe that it is a means to the end goal. Supporters of reservation state that giving an edge to women in the initial phase will help them make their presence felt in the decision making bodies. This will lead to situations where women will be in a place to actually have a say in the decisions and their implementation. Once this happens, the laws will automatically become more inclusive towards females, thus starting a chain reaction that will empower more women and subsequently enable them to achieve a status that is similar to that of their male counterparts.

On the other hand, many parties are opposing the bill due to various reasons. Prominent among them are is the bloc comprising of the Samajwadi party (SP), the Rashtriya Janta Dal (RJD), the Bahujan Samaj Party (BSP) and the Janta Dal United (JDU). These parties have presented a myriad of concerns regarding the bill. These parties have expressed concerns that as is observed from experience, a reservation once granted is very difficult to withdraw. This they say could lead to an undue advantage to women in the long run at the cost of their male counterparts. Another concern of those opposing the reservation is that it will disproportionately favour the women from metropolitan areas and from better socio-economic backgrounds while leaving the rural and backward women who are in dire need of their voice being heard in the lurch. The parties not in favour of the bill also express scepticism about the arrangement being arbitrary in nature due to the unequal distribution of the seats. They say it will be not a fair and equitable representation of the women of the country. The most serious concern however of these parties is that since independence, powerful male politicians have used the women of their families as their proxies when they are unable to get elected. So in theory, a woman has been elected to the legislative body but in reality, it is the male politician who is calling the shots and the elected female representative is merely a "Rubber Stamp." These concerns are the point of contention between the two sides of the debate.

\subsection{Women's Reservation And The Constitution}

The Constitution of India is the most supreme and sacred document of the country that is India. It provides for the rights of all those who seek its protection. The preamble to the constitution states that "People of India.. .secure to all its citizens...Justice... Liberty... Equality of status and of opportunity.. .and.. .Fraternity assuring dignity of the individual and the unity and integrity of the Nation."(Abhyankar, 1997). Furthermore, in cases of females, the Constitution not only guarantees equality guaranteed by Article 14 but also allows the state to use affirmative action or benign discrimination in order to further the cause of women. (Ray, 1999)

A close examination of the Constitution of India indicates that the Government was not only aware of the inherent inequalities between men and women, but intended to alleviate the problem through legislation. The articles of the Constitution explicitly provide that affirmative action for women is acceptable if done in furthering equality goals. Additionally, Indian case law has interpreted the Equal Protection provisions to permit the preferential 
treatment of women, through reservations or other means, without violating any specific constitutional provisions. (Ray, 1999)

Furthermore, in the case of Dattatraya Motiran More v. State of Bombay (1953), The court while dealing with the constitutionality of reserving seats for women in the Jalgaon Municipality election brushed aside the contentions of the petitioners that the reservation of seats for women was a violation of Articles 14, 15 and 16 of the Constitution and stated that such a reservation would not fall foul of the Constitution because it was based on consideration for the women's status and not merely on their sex. While giving this decision, the court also clarified that reservation for women would not violate Article 15(1) of the Constitution that prohibits discrimination the basis of sex. The court stated that Article 15(3) which empowers the state to make special reservations for women is in harmony with Article 15(1) and does not infringe upon the rights guaranteed by Article 15(1) in any way. Furthermore, when female reservation was made mandatory in the local bodies, Amendments were made to the Constitution and Articles 243D and 243T were added in order to legally guarantee the position of women in these decision making bodies. It is thus settled jurisprudence that reservation for women in the political arena is not in violation of the Constitution of India.(Dhavan, 2008)

\section{CONCLUSIONS AND SUGGESTIONS}

According to the Election Commission of India, women comprise nearly $49 \%$ percent of the country but are only $14 \%$ of the total membership of the Lok Sabha, the number for Rajya Sabha and State Assemblies is even worse, barely managing to get into double digit figures (Ministry of Finance, 208). The situation is so grim in fact, that in global rankings, India lags behind nations like Saudi Arabia and Pakistan where women have been given much lesser rights and status than that they are given in India. This gross underrepresentation of half of the country's population in its higher decision making bodies has led to a situation where women are dependent on the male politicians for dealing with laws pertaining to them. It is as if they are subjects of the making of the laws made for them, not equal stakeholders Dhavan, 2008). Quite ironically, when it comes to participation of women in the local bodies, India boasts one of the best female participation rates in the world. The situation in some places is so positive that women candidates have exceeded the 33\% reserved seats and are now comprising of nearly $50 \%$ percent of the elected representatives. It is truly baffling that a country where women are performing so well in local bodies are grossly underrepresented and outnumbered in the higher forums of legislation making. The success that the reservation for women in local bodies has portrayed can surely be a model that can be scaled up at state or national level. As the experience with local bodies has shown, the reservation serve as kick-starters for active female participation in politics which then acts as a catalyst for social change that brings about a promise to truly bring the women of India, who have been often treated as second class citizens, on an equal footing with their male counterparts in terms of rights, privileges and basic necessities of life. Also important to consider in this discussion are the recommendations made by the committee to which the Rajya Sabha had assigned the task of a detailed study of the bill. The committee had made several notable suggestions. Some of them are-

1) The bill, while empowering women and providing gender justice, also has the unique opportunity of empowering the minority of the third gender. According to the recommendation, the two seats reserved for the Anglo-Indians in the Lok Sabha are not in line with the population status of the community they were meant to represent as a large number of Anglo-Indians have either gone back to their native lands or have converted into full Indian Citizens. Thus it would be highly beneficial if the two seats were to be reserved for members from the third gender.

2) The committee also recommended that it would be problematic to find an equitable distribution of seats for the one-third reserved formula. Thus it would be better if the electoral representative system underwent reforms and make way for the provision of two member constituencies with one male and one female representative. This would ensure a more equitable and fair representation of women in the decision making bodies because it would effectively mean equal representation for men and women. (Regarding this point, I personally believe that with the next delimitation of constituencies due in 2026, it will be beneficial to synchronize both these activities as it would ensure a uniform method for induction of new members.)

3) The committee also recommended that the election process for Legislative Councils and the Rajya Sabha is not conducive for the implementation of reservation for women. Hence it would be beneficial to change the election procedure for these bodies or find a way to effectively implement reservation in these bodies.

If these recommendations and the concerns of the opposition are taken into consideration while passing the bill in an amended for, it holds the potential to catapult the nation into an era of effective gender justice and true equality for all. After all, as an old Chinese proverb goes, "Women hold up half the sky." 


\section{REFERENCES}

SINGHVI, Abhishek. (1997, September). The Women's Reservation Bill [Seminar Presentation]. Empowering Women Convention, New Delhi, India.

Facts and Figures on Hunger and Poverty, UN Women. Retrieved August 24, 2021, from Facts \& Figures | UN Women - Headquarters.

FORBES, Geraldine. (1996). Women in Modern India. Cambridge University Press.

https://doi.org/10.1017/CHOL9780521268127.

List of Laws related to Women, National Commission for Women. Retrieved August 27, 2021, from http://ncw.nic.in/important-links/List-of-Laws-Related-to-Women.

KAPUR, R., \& Cossman, B., (1996). Subversive sites: feminist engagements with law in India, Sage Publications. https://doi.org/10.1007/BF02684877.

RAY, Sumita. (2018). The Women's Reservation Bill of India: A Political Movement towards Equality for Women. 13 Temp Int'l \& Comp LJ 55.

National Public Radio (1998, July 15) National Public Radio: Women's Rights in India (NPR Morning Edition. (lexis transcript \# 98071514-210).

HANDOO Alka. (July 29, 1998). Gender Equity Put on Backburner, New Straits Times (Malaysia).

VIRK, Aviral. (July 23, 2018). All you need to know about the Women's Reservation Bill,, The Quint. All You Need to Know About the Women's Reservation Bill (thequint.com).

CHATTERJEE, Saubhadra. (March 8, 2017). Political will, patriarchy: Why the women's reservation bill has still not been passed, Hindustan Times. Political will, patriarchy: Why the women's reservation bill has still not been passed | Hindustan Times.

ABHYANKAR, Sharad. (1997). Constitutions Of The Countries Of The World-India. Oceana Publications. Dattatraya Motiran More v. State of Bombay, AIR. 1953 Bombay 311 (Vol. 40, C.N. 98).

DHAVAN, Rajeev. (2008). Reservations for Women: The Way Forward. National Law School of India Review 20, no. 1 (2008). https://www.jstor.org/stable/44283670.

Ministry of Finance. (2018). Economic Survey 2017-2018. Official Document: Economic Survey 2017-18: Volumes 1 and 2 - The Hindu Centre. 